\title{
The brand persona of a football manager - the case of Arsène Wenger
}

\author{
Adele Berndt \\ Media Management and Transformation Centre, Jönköping University, Jönköping, \\ Sweden and \\ Gordon Institute of Business Science, University of Pretoria, \\ Johannesburg, South Africa
}

\section{Brand persona of a football manager}

Received 30 January 2021 Revised 12 April 2021 13 May 2021 Accepted 22 May 2021

\begin{abstract}
Purpose - Sport is an important economic activity, and understanding the role of teams and managers is necessary, yet managers - specifically their brand personas - have been the subject of limited research. The purpose of this research is to explore the brand persona of a football manager, using Arsène Wenger as a case. Design/methodology/approach - Due to the exploratory nature of the study, qualitative methods were used to explore the brand-building activity. Media reports and images that centred on Arsène Wenger's words covering a three-year period were analysed. In total, 1364 articles and 23 images were analysed in NVivo, using both $a$ priori and emergent codes.

Findings - The findings show the construction of the brand persona in three main dimensions pertinent to his role as a manager. The first is the performance in the managerial role in which Arsène Wenger is appointed, the second is associated with the person (including emotions and self-expression) and the third is the context (i.e. football) in which the manager operates.

Research limitations/implications - The research focused on one manager while he was managing a premier league club and is limited to England.

Practical implications - While proposing a theoretical model, this study proposes football clubs understand a manager's persona in relation to the club's brand and the interactive effect. The support of the club on the persona is also indicated.

Originality/value - Football managers have received some research attention, but there has been no analysis of their brand personas. This study expands the understanding of the contribution of the manager to the club brand.
\end{abstract}

Keywords Brand persona, Human brand, Arsène Wenger, Arsenal, Football manager

Paper type Research paper

\section{Introduction}

Sport is a significant global economic activity, which was worth approximately US $\$ 620 \mathrm{bn}$ (Qara, 2019) with the revenue of English Premier League (EPL) teams exceeding £5bn in the 2018/2019 season (Ajadi et al., 2020). Football clubs can use branding strategies to connect with supporters and differentiate them from competitors (Anagnostopoulos et al., 2016; Bridgewater, 2010; Koenigstorfer et al., 2010). Club management is part of the club's branding strategy, including executive managers like the owners, directors and manager (Anagnostopoulos et al., 2016).

Managers like Arsène Wenger (AW) and Jürgen Klopp are the human faces of the football club brand and facilitate the team's performance on the pitch (Morrow and Howieson, 2014).

(C) Adele Berndt. Published by Emerald Publishing Limited. This article is published under the Creative Commons Attribution (CC BY 4.0) licence. Anyone may reproduce, distribute, translate and create derivative works of this article (for both commercial and non-commercial purposes), subject to full attribution to the original publication and authors. The full terms of this licence may be seen at http://creativecommons.org/licences/by/4.0/legalcode

The author wishes to thank the reviewers for the development of this paper. No funding was received for this research.

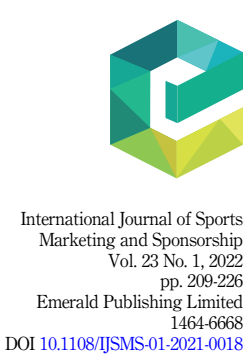


IJSMS

23,1

\section{0}

The manager is employed by the club to develop the strategy and fulfil numerous tasks, such as interacting with stakeholders (Kunkel and Biscaia, 2020), but primarily acting as the head coach (Kunkel and Biscaia, 2020; Morrow and Howieson, 2014), which is this study's focus.

Branding is not limited to products and services, but includes people (Kotler and Kotler, 2012). Human brands have been studied in numerous contexts, including academia (Close et al., 2011), artists (Muñiz et al., 2014; Schroeder, 2005), chief executive officers (CEOs) (Andreini et al., 2020; Bendisch et al., 2013; Chen and Chung, 2016, 2017) and politicians (Speed et al., 2015). In sport, studies have been conducted on the individual athlete (Arai et al., 2014; Lobpries et al., 2017), teams (Bauer et al., 2008) and leagues (Koenigstorfer et al., 2010; Kunkel et al., 2014).

Published research on football managers has focused largely on their leadership and management skills (Bridgewater et al., 2011), their tenure length (Hughes et al., 2010) and their dismissal from their managerial position (Arnulf et al., 2012). Research on managers has examined dress style (Bréhon et al., 2018) and the managers in relation to media (Carter, 2007) or as celebrities (Wagg, 2007). The impact football managers have on team success (and by implication, the club) (Wilson et al., 2019) and the players (Bridgewater et al., 2011) makes them a suitable study object, yet they have not been investigated personally or as the managerial representatives of the football club brand (Morrow and Howieson, 2014). Thus, this paper seeks to explore the brand persona of an EPL football manager - with AW as a case - using the brand identity theory, specifically personal, corporate and CEO branding (Abratt and Kleyn, 2012; Chen and Chung, 2017; Fetscherin, 2015; Montoya and Vandehey, 2009; Urde, 2013).

This study contributes to human branding and sports marketing literature. It identifies pertinent areas to assist in understanding the development of a human brand identity (specifically brand personas) - a concept that requires further research (Kapferer, 2012) within a football context. While managing a club brand has become increasingly important (Bouchet et al., 2013), the manager's brand identity has not been researched, despite managers impacting club perceptions and branding (Taniyev and Gordon, 2019).

This paper reviews perspectives on human brands and personas, after which the methodology and findings are presented. The paper concludes with a discussion, implications and future research.

\section{Theoretical framework}

\section{People as brands}

A brand is a name and/or symbol used to distinguish a product, service or organisation from its competitors, being extended to include people like celebrities, journalists, CEOs (Gad and Rosencreutz, 2002; Lair et al., 2005; Lunardo et al., 2015) and athletes (Arai et al., 2014; Kristiansen and Williams, 2015).

Various terms that reflect diverse perspectives have been used to describe people as brands, including a personal brand, human brand and celebrity, all of which could be appropriate when discussing football managers. A personal brand describes the creation of an identity using "your values, personality, your expertise that makes you unique" (Montoya and Vandehey, 2009, pp. 4-5), with football managers having experience, education and a driving passion for football (Morrow and Howieson, 2014). "Human brand" also describes a football manager who acts as a spokesperson to endorse various brands (Arai et al., 2014; Koo, 2009; Lunardo et al., 2015). A celebrity is "an individual whose name has attention-getting, interest-riveting and profit-generating value" (Rein et al., 2006, p. 17), with managers being in the spotlight (Carter, 2007), and their actions being analysed by the media (Bridgewater, 2010). 


\section{The brand persona}

A brand identity is transmitted through a brand persona, reflecting an individual's relationship with society (Dion and Arnould, 2016). The persona is where a person's private life becomes public (Tolson, 2001) and is associated with a specific role rather than the actual person (Dion and Arnould, 2016) or their personality (Osorio et al., 2020). Individuals create their brand persona through their activities, decisions and actions, and language (Centeno and Wang, 2017; Schroeder, 2005). They publicly present their values, personal style and other visible representations (Centeno and Wang, 2017; Rein et al., 2006). In this study, persona is used to describe what "the human brand wishes to project" and what is communicated (Speed et al., 2015, p. 141).

\section{The football manager as a brand persona}

The term "manager" has been used in football to describe the person responsible for "determining the sports strategy" (Kunkel and Biscaia, 2020, p. 8). The manager is employed with the primary responsibilities of coaching the first team's performance on the pitch (Morrow and Howieson, 2014) and delivering results (Wilson et al., 2019), although these responsibilities may vary between clubs (Schyns et al., 2016) and leagues in different countries. The team performance enables qualification for lucrative competitions, impacting the club's profitability and reputation, putting pressure on the managers (Wilson et al., 2019). Managers may fulfil numerous other tasks, such as interacting with stakeholders (e.g. the media (Bridgewater, 2010), depending on the club's managerial model (Morrow and Howieson, 2014; Schyns et al., 2016)).

\section{Perspectives used to research the brand persona}

Various streams of brand identity literature can assist in understanding a football manager's brand persona, including personal, corporate and CEO branding literature (Chen and Chung, 2016; Fetscherin, 2015; Gad and Rosencreutz, 2002). These perspectives are outlined below.

The personal branding perspective focuses on the individual characteristics used to differentiate a person and is associated with personal skills, motivation and interest (Chen and Chung, 2017; Lair et al., 2005; Montoya and Vandehey, 2009) in labour (or career) market (Gorbatov et al., 2018) and social networks (Osorio et al., 2020). This perspective presents each individual as the CEO of "Brand You", namely, that each person is a brand (Gad and Rosencreutz, 2002). McNally and Speak (2011, p. 44) identified three dimensions of a personal brand - brand roles, brand standards and brand style. A brand role suggests that diverse roles require different actions, resulting in different personas. Brand standards reflect the performance levels necessary for the various roles (i.e. how well it is carried out) to support a perception of competence, while the brand style reflects the communication and interaction style used, including language and clothing (Bréhon et al., 2018).

The corporate branding perspective views a corporate brand as "the sum of the values" (Tarnovskaya and Bertilsson, 2017, p. 46) and features used by an organisation to create a unique identity, serving as its external representation through its behaviour and communication (Kapferer, 2012; Van Riel and Balmer, 1997), consequently building trust, loyalty and commitment. Corporate branding research (Abratt and Kleyn, 2012; Van Riel and Balmer, 1997) identifies various components of corporate brand identity, including the strategy, culture and structure (strategic choices), and corporate expression (e.g. visual identity and brand promise) (Abratt and Kleyn, 2012; Balmer and Gray, 2003).

The CEO branding perspective views CEOs as brands (Andreini et al., 2020; Bendisch et al., 2013), with a successful CEO brand improving the brand value (Chen and Chung, 2017). The CEO brand consists of two main parts: brand reputation (prestige and performance) and the brand image (persona and personality) (Fetscherin, 2015). In this literature, brand reputation

Brand persona of a football manager 
IJSMS

23,1

212 refers to stakeholder perceptions (Bendisch et al., 2013), specifically prestige and performance. Prestige is the reputation the CEO has among stakeholders, while performance refers to a CEO's financial (e.g. return on investment, profits) and nonfinancial (e.g. motivational impact) results (Fetscherin, 2015) and the competencies that improve organisational efficiency (Chen and Chung, 2016). Brand image includes the CEO's power and impression ("look"), while the personality denotes the CEO's traits and the effect they have on the organisation (Bendisch et al., 2013; Chen and Chung, 2016).

\section{Integrating the perspectives: the approach in this study}

The three theoretical perspectives of human brands are relevant in exploring human brands, as reflected in Table 1. Integrating these perspectives allows for the understanding of the complexity and richness of brand personas and their components as they highlight different aspects of the human brand. The personal branding perspective presents the person undertaking a specific role (Gad and Rosencreutz, 2002) focusing on the individual's personal characteristics (Osorio et al., 2020). Corporate branding suggests that people can become corporate brands that they own and manage (Pihl, 2013). It highlights the values and culture that reflect "who we are" (strategic choices) in the development of brand identity (Abratt and Kleyn, 2012; Balmer and Gray, 2003; Rein et al., 2006) and is evidenced in behaviour (Van Riel and Balmer, 1997). The CEO branding literature identifies the transfer of the CEO's characteristics to the brand, which, in this instance, is the person and how these characteristics affect the brand persona (Scheidt et al., 2018). Visual and verbal expressions, including language, appearance and clothing, are evidenced in all the perspectives, using diverse terms to describe them (Bendisch et al., 2013; Van Riel and Balmer, 1997). A football manager has personal characteristics (personal branding) that they use to build their overall brand (corporate brand) while making brand decisions as the CEO (owner) of their human brand.

\section{Methodology}

Similar to other research (Kristiansen and Williams, 2015), a case study analysis was implemented, enabling the investigation in one context (Flyvbjerg, 2011). A case is used to discover unique insights where limited research has been conducted (Streb, 2010), making it relevant to answer the research purpose.

\section{Selection of the context}

The first step in the selection of the context (Flyvbjerg, 2011) was to identify a suitable league, club and manager. The EPL was selected from the world's football leagues as it has the highest revenues, with ten of the 20 top clubs being from this league (Boor et al., 2018). The ownership of clubs in the EPL was examined, and an American-owned club was selected as

Table 1.

Integrating the diverse perspectives identified in the literature

\begin{tabular}{lll}
\hline Personal branding perspective & $\begin{array}{l}\text { Corporate branding } \\
\text { perspective }\end{array}$ & CEO branding perspective \\
\hline Performance standards (i.e. how it is done) & $\begin{array}{l}\text { Strategic choices (e.g. culture, } \\
\text { values and mission) } \\
\text { Expression (i.e. visual }\end{array}$ & $\begin{array}{l}\text { Brand reputation (i.e. } \\
\text { prestige and performance) } \\
\text { Brand image (i.e. person and } \\
\text { personality) }\end{array}$ \\
$\begin{array}{l}\text { Brand style (i.e. communication and } \\
\text { interaction, including language and dress) }\end{array}$ & $\begin{array}{l}\text { identity) } \\
\text { Role played (such as manager or coach) }\end{array}$ &
\end{tabular}

Source(s): Abratt and Kleyn (2012), Fetscherin (2015), McNally and Speak (2011), Urde (2013) 
these owners have invested in other sports teams, which impacts their management philosophy, with a focus on profitability (Rohde and Breuer, 2017). Arsenal is one of the most successful clubs in the EPL, having won 45 trophies and experienced managerial stability in recent years, making AW a suitable case for further investigation.

\section{The case - Arsène Wenger}

As Arsenal's manager, AW was one of the longest serving managers in the EPL. He initially played football for amateur clubs and then went on to play for Strasbourg in the French league. In 1981, he completed his coaching qualifications and was appointed at Cannes, Nancy and later Monaco. AW was recruited to Arsenal while coaching in Japan and arrived as a relatively unknown manager in 1996, bringing a scientific approach to training. During his time at Arsenal, the club won three EPL titles and seven Football Association (FA) Cups. In 2004, the team (nicknamed "The Invincibles") was unbeaten throughout the season. AW left Arsenal at the end of the 2017/2018 season (Associated Press, 2018; Daily Mail, 2018).

\section{Data collection}

Similar to Bréhon et al. (2018) and Wagg (2007), to examine the public persona, media articles and materials on AW were collected from leading online newspapers (e.g. Daily Mail, The Independent) using the name "Arsène Wenger" as the search term, enabling content analysis (Bowie, 2019). Media articles analysed were authored by press agencies (e.g. Associated Press, Reuters) and independent sports journalists (e.g. Mokbel, Mann-Bryans). Articles from the past three years of AW's EPL career (1 August 2015 to 30 June 2018) were selected for analysis to gain a comprehensive view and collect rich data to explore how AW described himself as a brand owner using his own words. Initially, the plan included the use of social media (e.g. Facebook and Twitter specifically), but there were 114 AW Facebook pages all claiming to be "the original Arsène Wenger", and a similar situation was identified on Twitter. Consequently, the decision was made to exclude social media.

Initially, 17,383 results covering three EPL seasons (2015-2018) were downloaded and analysed. Duplicate articles and match reports or articles not containing quotes (or the words) of AW (the brand owner) were removed, resulting in 1,364 unique documents and 23 images. The images included AW at training sessions, pre- and post-match press conferences, and pitchside during matches.

\section{Data analysis}

All media pages were analysed using NVivo as PDF documents or images. Coding involves compiling defined codes and then "judging a segment of text whether a specific code is present” (Hruschka et al., 2004, p. 308). Two a priori codes (strategic choices and expression) were created initially based on the literature review, but the analysis of the material resulted in the expansion of these codes and the identification of emergent codes. For example, the strategic choices code was expanded to include player management, tactics, management philosophy and the club. Furthermore, issues like external factors (e.g. the FA and supporters) were developed as emergent codes. A coding framework (Table 2) was developed to assist in ensuring the validity of the data (Barbour, 2001), which contains the various codes and their definitions.

All the unique pages were coded by the researcher. An independent coder was used to verify the coherency and accuracy of the coding (Marquardt et al., 2017). The coder was briefed on the purpose of the study, the draft coding sheet was discussed and a pilot coding of ten articles was completed after which the coder verified a random sample of $10 \%$ of the 
IJSMS

23,1
A priori

(theoretical) Expanded (emergent

\begin{tabular}{lll} 
codes Definition & codes) \\
\hline
\end{tabular}

Strategic The management style, values and Managerial

choices strategy that comprise the manager's job (Abratt and Kleyn, 2012), i.e. performance

\section{4}

Expression

Includes verbal and visual expression (self-presentation) and personality (Abratt and Kleyn, 2012; Bréhon et al., 2018)

The environment and external factors (i.e. the context of the task) philosophy

Player management philosophy

Tactics

The club

Personality

Emotions

Expressive style

Supporters

External parties (e.g. professional bodies, media)
Nature of themes

Team management, including underlying philosophies and values The approach to interacting with the athletes who form part of the team

The style and approaches to play

Finances, club management and transfer policy

Individual characteristics

The range of emotions (feelings) reflected in carrying out their task The words used, communication and the clothing worn Club fans

Table 2 .
Coding framework used in the data analysis
Parties that impact team management

articles (Lombard et al., 2002). This was done to evidence credibility and trustworthiness of the coding process. Inter-rating agreement of $85 \%$ was achieved, and disagreements were resolved through discussion (Campbell et al., 2013). The quotes provided in the findings reflect the informant-centric terms used to develop second-order themes and provide clarity on the various themes and patterns in the data (Lingard, 2019).

\section{Findings}

AW's role has a brand constructed in a specific professional area - i.e. in sport, coaching various teams. It impacts the way in which he constructs his brand, and the analysis indicates his awareness to build and manage his persona. For example, when talking about his personality trait (humour), AW describes it as being "something that I obviously cannot do in front of the media" (cited in Snowball, 2015), reflecting the awareness of the public nature of his role.

Using the a priori and emergent codes (e.g. player management, tactics and supporters), three dimensions of the football manager persona were identified. These dimensions - the performance (management of the players and team), person (expressions) and context in which the persona is constructed - are used to organise and report the findings. Additional quotes are presented in Table 3.

\section{Performance - strategic choices (management philosophy, player management philosophy and tactics)}

Performance refers to the role of a manager and is reflected in the managerial approach used to exploit the talents of players and support staff and evaluate them, as summarised in AW's managerial philosophy: 
Performance

Managerial philosophy

Player management philosophy

Tactics

The club

Person-expression

Personality

Emotions

Expressive style

Context

The supporters

External parties
"I am accountable on the results of my team and the way they play football" (Cross, 2015)

"In my line of work, we are constantly making decisions that punish people, while making others happy" (English, 2018)

"That is our structure of the team, to attack. If you get our players to defend then I do not think we will be so efficient. We have to play every time we can" (Grohmann, 2015)

"I am appointed to perform and do the best for my club. It's all I focus on" (Bretland, 2016)

"I have no doubt, no, because I am committed. When I do something I do it 100 percent. I am always committed to give my best as long as I am at the club” (Bretland, 2016)

"I'm a passionate guy and I believe that I am completely committed in my job and want to win football" (EPSN Staff, 2017)

"In life, I look at what people do, not at what they say. [...] You ask me my commitment, and my attitude is dictated by what I did in my life, not by what I say in a press conference" (Hytner, 2018)

"I always say when you wake up in the morning and you can go to a football game, you hope it can be a moment of happiness in your life. We have to try to give that to people" (Lawrence, 2018)

"...people who comment, their job is to comment, so you have to live with that" (Mokbel and Williams, 2018)
Brand persona of a football manager

Table 3.

Representative quotations underlying second-order themes

There are three main elements to management. The first is the style of play and the results. The second is the individual development of the players ... Thirdly, the structure and values you want to integrate into the club (cited in English, 2018).

AW is determined to give his best to the team and the club to enable it to succeed, reflecting what he considers his first principle of management, with managerial decisions and actions taken to deliver the best results (i.e. wins). While winning is his goal, AW knows this is not always possible, as defeat is part of sport. He describes losing as "suffering" (cited in Langshaw, 2018) or "a scar for life. Each will forever be a great disappointment" (cited in English, 2018).

A player management philosophy refers to the approach used with the players and the team, with the manager employing football players' skills on the pitch to deliver the desired results. The squad system means that some players will not be selected, resulting in disappointed players: "When you work with a 25 -man squad, it's basically making 14 people unemployed every Saturday or Tuesday" (cited in English, 2018). AW also defends his players from criticism from the media and does not criticise them publicly: "you have to control what you say" (cited in PA Sport, 2017).

The tactics are planned prior to a match and then implemented on the pitch. Determining the style of play is a primary coaching task and involves the development of the team's mental and physical attributes. AW suggests it is about players' mental beliefs, which are reflected in the style of play (physical). The outcome of this positivity is seen in the style of play, as AW points out: "We are an attacking side ... I do not think you can pretend to be a big club and say we only want to defend" (cited in Callow, 2016).

The club employs the manager, and the owners provide support to the manager, which is necessary for any manager (Mokbel and Morshead, 2017). The club has objectives that the 
IJSMS

23,1

\section{6}

First-order concepts

The importance of winning

Coming back from the disappointment of defeat

The importance of attitude on the pitch

Player selection

Getting the best out of the players on the pitch

Protecting them from external criticism

Beliefs and attitudes of players reflected in their play

Reputation for a style of play (attacking side)

Specific tactics (defending, attacking, holding the ball)

Heritage

Management and strategic goals

Transfer policy

Finances

Competitive nature

Personality traits (integrity, honesty, loyalty)

Passionate

Control of emotions

Range of emotions

Communication and visual style

Relationship with supporters

Getting behind the team and the club

Professional bodies (FA, UEFA, FIFA)

The media/pundits and commentators

Figure 1.

Data structure

Other clubs
Second-order themes

Aggregate dimensions

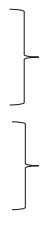

Managerial

philosophy

Player management philosophy

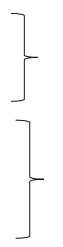

Tactics

The Club

Personality

\}

Emotions

Expressive style

Supporters/Fans

External parties
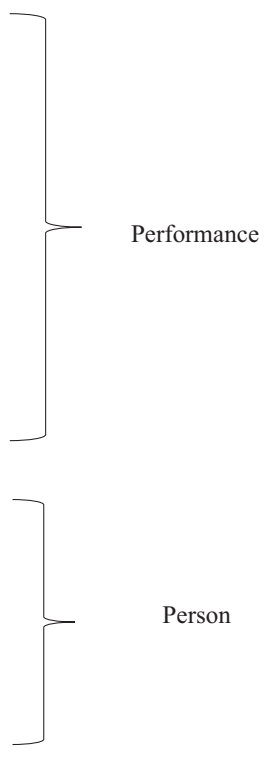

Person

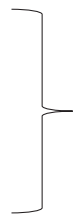

Context

manager is employed to achieve, such as winning league and competition trophies, which affect financial performance. Arsenal experienced financial pressure moving to a new stadium, The Emirates (Moore, 2018), which impacted the ability to sign new players and the need to sell players to reduce wages. This caused friction with supporters, as new players were not added to the squad. AW described it as follows: "We had to sell our best players every year to survive, but we did not do three years out of five in the Champions League" (cited in PA Sport, 2016a). Responding to structural changes within the club and the possible appointment of a director of football, AW said: "As long as I am the manager of Arsenal Football Club I will decide what happens on a technical front" (cited in Barlow and Mokbel, 2017).

Person - expression (personality, emotions and expressive style)

The second area identified is the person (AW) who fulfils the role, reflecting the expressive aspects of his person, including personality, emotions and communication. AW described his personality, specifically his competitive nature as follows: "You have seen the real Arsène Wenger, one aspect of me, which is a desperate guy who wants to win football games" (cited in Mann-Bryans, 2018; cited in Press Association, 2018). AW's personality traits include a high level of commitment and identification with the club, integrity, honesty, resilience, passion and loyalty. He indicated that he would not write a book while in active management 
as his honesty "would land him in trouble" and, as he states, "I do not like to talk and not tell the truth" (cited in Al-Samarrai, 2017). His commitment to the club is evident in his approach to his job: "What is most important is that I give my best every day I work for the club I love" (cited in Bretland, 2016). Knowing he was to depart from Arsenal, AW expressed the desire to leave the club in a position that would enable it to succeed in the future:

My great pride will be to be able to say the day that I leave, that I am leaving behind a good team, a healthy situation and a club capable of performing in the future (cited in Godden, 2015).

Emotions for football and the club (Arsenal) are detailed in this theme. AW describes himself as a passionate person, reflected in his commitment to the role. Despite this passion, he describes the need to control the emotions as part of his survival, which enabled him to do his job. "I'm very passionate and at a very young age, I realised that if I wanted to survive in this job, I had to get control of my emotions or I would not survive", describing it as controlling "the animal that is inside you" (cited in Mann-Bryans, 2018; cited in Press Association, 2018). Other emotions identified include regret, sadness and frustration associated with defeats and events on the pitch: "I was sad and upset more by the result than by the individual reactions of people, which I can understand" (cited in PA Sport, 2016c).

Expressive style, including communication and the visual style, were identified in how AW interacts with others. His communication is built on honesty, but also on an awareness that the persona presented in public needs to be managed, thus determining what information should be shared - "I do not have to give you all the information regarding my decisions" (cited in Cross, 2015). AW believes that actions rather than words are important:

I do not worry what you say about me or what fans say about me. I try to do my job in a proper way and with full commitment. After that everybody has the right to have an opinion (cited in Press Association, 2016).

The importance of the tone in communication in addition to the words were mentioned and that "yelling these days will get you nowhere" (Al-Samarrai, 2017).

An analysis of the images indicates a manager who dresses to support his role. At training and pre-match conferences, AW appeared in tracksuits (or activewear), supporting the role of a coach. By contrast, when watching games, AW wore a formal shirt, a tie and trousers. While the shirt was white or blue, he always wore the red Arsenal tie and a jacket with the club's emblem, even in warm weather. In colder weather, AW donned an official Arsenal puff jacket.

\section{Context (supporters and professional associations)}

The third area is the context, which presents challenges to the football manager, such as pressure from supporters and regulatory bodies as stakeholders who observe how AW performs his role. These contextual aspects influence how AW carries out his role as manager and may impact the persona.

The club supporters are important from financial and non-financial perspectives, purchasing tickets and merchandise and contributing to stadium atmosphere. AW acknowledges his impact on the supporters as a point of connection to the club: "That gives a club a responsibility. You have people who you know will go home and cry when you lose a game, who will suffer when you do not play well" (cited in Lawrence, 2018). Their dissatisfaction with AW was acknowledged to impact his decision whether (or not) to sign a contract extension: "Yes, fans' opinion will have an impact on my decision, you consider everything. It will not be the most important factor, but of course, you consider it" (cited in Mokbel, 2017c).

Football is managed by various professional associations (e.g. the FA, UEFA) and external parties, and in the role of a football manager, these external parties impact the way
Brand persona of a football manager 
IJSMS

23,1

\section{8}

AW implements his role. The FA manages the game in England by appointing and managing referees and implementing rule changes. AW's attitude is that "they (referees) are professionals" (cited in Robinson, 2016), yet managers do not always agree with the referees' decisions. For instance, when Arsenal played a match against Burnley in 2017, AW reacted angrily to the referee's decision, which resulted in AW being sent off and later disciplined by the FA (Mokbel, 2017b). Other external parties include the media and the commentators reporting on the games, who serve as the link between the manager and various stakeholders. The media channels what AW says to a broader audience and is then able to use this to influence external stakeholders' perceptions. AW is aware that a football manager is a "public-facing job" (cited in English, 2018) that attracts media attention. The media comments on the manager's decisions, including criticism and publishing stories that may not be true, which happened when AW arrived in the EPL: "They ran a lot of stories. A lot of lies" (cited in English, 2018). Nevertheless, AW acknowledges that he is not surprised by the criticism (PA Sport, 2016b).

\section{Discussion}

This research's purpose was to explore the brand persona of a football manager to understand a specific human brand, using AW as a case. Various branding lenses can be used to understand the construction of a human brand, but while previous research has suggested some critical areas for a persona (Chen and Chung, 2016; Dion and Arnould, 2016; Fetscherin, 2015), the brand identity of football managers has not been explored.

Individuals are unaware of their brand (Murray, 2017), yet analysis of the case shows an awareness of the need to present an identity in public, specifically as there are issues not brought into the public domain or discussed, similar to Bréhon et al. (2018). This suggests that, in this role, there is a conscious and deliberate effort to build a persona.

This study has identified three aggregate dimensions - the performance, the person and the context within the role being carried out. As suggested in the literature (Bendisch et al., 2013; Close et al., 2011; Dion and Arnould, 2016; Wilson et al., 2019), the importance of performance was acknowledged by AW, who identifies the need to win games as important to him, the club and the supporters. Performance was established as a vital dimension of the personal brand and CEO brand (Chen and Chung, 2017; McNally and Speak, 2011), and the importance of the team's performance is evident among football managers (Bridgewater, 2010; Herskedal, 2017). Managerial decisions, such as team management and tactics, contribute a range of outcomes, including finances, stadium atmosphere and fan enthusiasm (Wilson et al., 2019), as suggested by the corporate branding perspective. For example, with Arsenal not qualifying for the Champions League in 2017, the club reduced the price of season tickets for the following season (Mokbel, 2017a). Performance also impacts the brand associations of stakeholders (Andreini et al., 2020), the attraction and loyalty of fans (local and distant) (Bauer et al., 2008; Bodet et al., 2020) and sponsorship arrangements (Koenigstorfer et al., 2010). The owners' impact on the decision to support or dismiss managers is identified in previous research (Bréhon et al., 2018; Herskedal, 2017; Rohde and Breuer, 2017) and acknowledged by AW.

Similar to Bendisch et al. (2013), Carter (2007) and studies into CEOs (Chen and Chung, 2016; Fetscherin, 2015), this study identifies the importance of the person in the development of identity. Personality traits have been identified as factors in a manager's role, together with a passion for football and a desire to be involved with it (Herskedal, 2017; Koo, 2009). The role of emotions within a human brand has been highlighted in this study and requires further research because of its significance in this context. For example, "passion" towards football was identified by AW. This refers to the "strong inclination toward an activity that people like, that they find important, and in which they invest time and energy" (Vallerand et al., 
2003, p. 757). This supports the view of Anagnostopoulos et al. (2016), who suggested that passion among those working in team sports is part of their identity. Visual expression (clothing) reflects various roles (manager, coach), and analysis of the images supports the findings of Bréhon et al. (2018) and their categorisation of football managers. AW's professional approach to the game is reflected in the clothing (a suit), which is described by Bréhon et al. (2018) as a style known as "the boss". The demographics of AW (age and nationality) could impact his clothing decisions and a desire to create a perception of competence among supporters, as these are personal choices (Bréhon et al., 2018).

Concerning the context, the dynamic and complex nature of supporters, sports organisations (Anagnostopoulos et al., 2016) and the media also contribute to AW's brand persona. From a financial perspective, the significant role of supporters (purchasing tickets and merchandise) and AW's acknowledged role in this relationship supports the research of Wagg (2007). The FA affects managerial decisions, including the number of foreign players who can play for a team (Pitt-Brooke, 2018), and managerial comments, acknowledged by AW. The media communicates the managers' brand persona, presenting them as celebrities (Carter, 2007; Herskedal, 2017), influencing stakeholder perceptions.

\section{Implications for theory and practice}

The study contributes to human branding, specifically personal and CEO branding, by reflecting the importance of the person when carrying out a specific role (McNally and Speak, 2011), yet extends this perspective to include the identification of external factors. The importance of emotions is also seen in the data. The role of corporate branding is seen in the mission, values and culture of the brand owner (AW), including the verbal and visual style, which are reflected in his presentation (Harris and de Chernatony, 2001). While the theoretical perspectives (specifically personal and CEO branding) acknowledge the role of performance, emergent codes show the importance of team and player management as specific performance areas. Using these diverse streams of literature, thus, encourages viewing identity from a long-term perspective (Lobpries et al., 2017).

The contribution to sports marketing is in the analysis of the manager's (or sender's) perspective of a brand. Previous research has examined branding of individual athletes (Hasaan, 2016; Kristiansen and Williams, 2015; Lobpries et al., 2017), and with the importance of the managers' brands both to the individual and to the club, three focus areas for managers' branding are suggested.

Practical implications can be drawn from this research for managers, clubs, and sports marketers. For managers, an awareness of their brand persona and its management can influence a range of choices. These include how their person (e.g. personality and passion) can be used to build their brand as they can assist in transferring positive brand perceptions (Scheidt et al., 2018). For example, how the manager discusses team and player management issues impacts stakeholder perceptions. As clothing and other symbols (e.g. glasses) together with verbal expression can impact stakeholder perceptions of managerial competence and of the team (Koo, 2009), these need to be carefully considered. Managers can be trained and supported in how to build an effective brand persona (Wilson et al., 2019) including the skills to enable them to deal with pressure in difficult times, such as poor performances. Moreover, the management of a brand strategy requires the monitoring the brand persona as changing football seasons and club and team matters can impact fan perceptions. Social media has become vital in the management of the relationship between the club and fans ( $\mathrm{Pu}$ and James, 2017), and professional assistance in managing the brand persona is recommended.

For sports teams and sports marketers, the manager's persona impacts the club's branding strategy, and this can be used to strengthen and improve the club identity (Keshtidar et al., 2018) as the manager forms a part of the "product" aspect in the club's branding strategy
Brand persona of a football manager

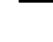


IJSMS

23,1

220

(Koo, 2009). This includes managing media exposure as this impacts brand communication (Kristiansen and Williams, 2015). The manager's brand can also be used to develop the relationship with existing fans (e.g. fan identification) and attract new fans (Hasaan et al., 2016). This can be done via advertising and public relations campaigns to make the manager more identifiable (e.g. by providing events to meet the manager). Managers serve as a symbol to a local community (Heere and James, 2007), thus using the manager to implement corporate social responsibility activities (e.g. at Christmas) can contribute positively to the club brand (Koo, 2009). The club strategy (e.g., finances and goals) impact the actions and decisions of the manager and recognition of this interdependence and its impact on both brands is necessary. Coherence between the brand persona of the manager and club is a further practical implication of this study. Employing a manager whose persona is inconsistent with the club's brand identity can cause brand conflict, which will be disadvantageous for both parties.

\section{Conclusion, limitations and future research}

The study's limitations include the use of one manager in one industry (Kristiansen and Williams, 2015), i.e. Arsenal, the EPL and AW and his subsequent departure from Arsenal. The use of online sources is a further limitation. Newspapers (both online and offline) can serve as an effective research tool as they cater for specific audiences (Bowie, 2019), yet it is not possible to verify whether they are similar or different from print editions (Schafraad et al., 2006). Reports were only taken from English online sources due to the location of the chosen club and access to AW. Furthermore, images from AW's private life were not analysed as they were not connected with his task at the club. Social media is important in branding, but these platforms were excluded from analysis due to the multiple accounts, the owners of which could not be verified.

This study has numerous future research opportunities. For instance, the identified dimensions could be evaluated in various leagues and countries and in other human brand contexts (e.g. higher education). Including other football managers from the EPL and other leagues can facilitate comparison and the development of archetypes and the impact of the context on the development of brand personas. Comparisons between football managers and managers in other leagues and sports (e.g. baseball and ice hockey) reflect opportunities for developing sport-specific models for understanding sports managers' brands. Private lives are increasingly considered newsworthy (Summers and Morgan, 2008); hence, future research can investigate the impact on the football manager's brand identity. Examining how other stakeholders, such as supporters and ex-players, perceive these human brands will indicate the coherence of the manager's brand persona among diverse audiences.

Noting football's importance to the economy and the significance of football clubs within society, it is necessary to understand how football managers construct their brands in this dynamic context. By analysing written and photographic evidence of one manager, this study has identified the performance, person and context as key aspects of a brand persona.

\section{References}

Abratt, R. and Kleyn, N. (2012), "Corporate identity, corporate branding and corporate reputations: reconciliation and integration”, European Journal of Marketing, Vol. 46 Nos 7/8, pp. 1048-1063.

Ajadi, T., Ambler, T., Udwadia, Z. and Wood, C. (2020), Home Truths Annual Review of Football Finance 2020, Deloitte, Manchester.

Al-Samarrai, R. (2017), "Arsenal Boss Arsene Wenger will not follow Tottenham manager Mauricio Pochettino into publishing a book: 'I don't like to talk and not tell the truth', Daily Mail, London, available at: https://www.dailymail.co.uk/sport/football/article-5094135/Arsenal-boss-ArseneWenger-won-t-publish-book.html (accessed 20 November 2018). 
Anagnostopoulos, C., Winand, M. and Papadimitriou, D. (2016), "Passion in the workplace: empirical insights from team sport organisations", European Sport Management Quarterly, Vol. 16 No. 4, pp. 385-412.

Andreini, D., Fetscherin, M. and Zarantonello, L. (2020), "How a CEO's personality, performance, and leadership predict advertising credibility: conceptualizing and measuring CEO brand image", Journal of Advertising Research, Vol. 61 No. 1, pp. 10-24.

Arai, A., Ko, Y.J. and Ross, S. (2014), "Branding athletes: exploration and conceptualization of athlete brand image", Sport Management Review, Vol. 17 No. 2, pp. 97-106.

Arnulf, J.K., Mathisen, J.E. and Hærem, T. (2012), "Heroic leadership illusions in football teams: rationality, decision making and noise-signal ratio in the firing of football managers", Leadership, Vol. 8 No. 2, pp. 169-185.

Associated Press (2018), "Wenger won't retire after leaving Arsenal at end of season", available at: https://www.dailymail.co.uk/wires/ap/article-5655835/Wenger-wont-retire-leaving-Arsenal-endseason.html (accessed 15 September 2018).

Balmer, J.M.T. and Gray, E.R. (2003), “Corporate brands: what are they? What of them?”, European Journal of Marketing, Vol. 37 Nos 7/8, pp. 972-997.

Barbour, R.S. (2001), "Checklists for improving rigour in qualitative research: a case of the tail wagging the dog?", BMJ, Vol. 322 No. 7294, pp. 1115-1117.

Barlow, M. and Mokbel, S. (2017), "Arsene Wenger rubbishes talk of Arsenal director of football 'As long as I am the manager I will decide what happens"', Daily Mail, London, available at: https:// www.dailymail.co.uk/sport/football/article-4487598/Arsene-Wenger-rubbishes-Arsenal-directorfootball-talk.html (accessed 20 November 2018).

Bauer, H.H., Stokburger-Sauer, N.E. and Exler, S. (2008), "Brand image and fan loyalty in professional team sport: a refined model and empirical assessment", Journal of Sport Management, Vol. 22 No. 2, pp. 205-226.

Bendisch, F., Larsen, G. and Trueman, M. (2013), "Fame and fortune: a conceptual model of CEO brands", European Journal of Marketing, Vol. 47 Nos 3/4, pp. 596-614.

Bodet, G., Geng, H.E., Chanavat, N. and Wang, C. (2020), "Sport brands' attraction factors and international fans", Sport, Business and Management, Vol. 10 No. 2, pp. 147-167.

Boor, S., Hanson, C. and Ross, C. (2018), Rising Stars Football Money League, Deloitte Sports Business Group, Manchester, available at: https:/www2.deloitte.com/content/dam/Deloitte/ uk/Documents/sports-business-group/deloitte-uk-sbg-dfml2018.pdf (accessed 15 December 2019).

Bouchet, P., Hillairet, D. and Bodet, G. (2013), Sport Brands, Routledge, London.

Bowie, D. (2019), "Contextual analysis and newspaper archives in management history research", Journal of Management History, Vol. 25 No. 4, pp. 516-532.

Bréhon, J., Neys, O.H. and Juskowiak, H. (2018), “Tracksuit' or 'business suit'? Effects of the clothing styles of French professional football managers", Sport in Society, Vol. 21 No. 11, pp. 1721-1738.

Bretland, E. (2016), "Arsenal Boss Arsene Wenger in "no doubt" he will remain at emirates next season”, Daily Mail, London, available at: https://www.dailymail.co.uk/sport/football/article3513026/Arsenal-boss-Arsene-Wenger-no-doubt-remain-Emirates-season.html (accessed 20 November 2018).

Bridgewater, S., Kahn, L.M. and Goodall, A.H. (2011), "Substitution and complementarity between managers and subordinates: evidence from British football”, Labour Economics, Vol. 18 No. 3, pp. 275-286.

Bridgewater, S. (2010), Football Brands, Palgrave Macmillan, Basingstoke, Hampshire.

Callow, N. (2016), "Arsene Wenger defends Arsenal's attacking principles...despite scoring fewer goals than any other team in the top four", Daily Mail, London, available at: https://www.

Brand persona of a football manager 
IJSMS

23,1

dailymail.co.uk/sport/football/article-3543671/Arsene-Wenger-defends-Arsenal-s-attackingprinciples-despite-scoring-fewer-goals-team-four.html (accessed 20 November 2018).

Campbell, J.L., Quincy, C., Osserman, J. and Pedersen, O.K. (2013), “Coding in-depth semistructured interviews: problems of unitization and intercoder reliability and agreement", Sociological Methods and Research, Vol. 42 No. 3, pp. 294-320.

Carter, N. (2007), "Managing the media': the changing relationship between football managers and the media”, Sport in History, Vol. 27 No. 2, pp. 217-240.

Centeno, D. and Wang, J.J. (2017), "Celebrities as human brands: an inquiry on stakeholder-actor co-creation of brand identities", Journal of Business Research, Vol. 74, pp. 133-138.

Chen, H.M. and Chung, H.M. (2016), "How to measure personal brand of a business CEO", Journal of Human Resource and Sustainability Studies, Vol. 4 No. 4, pp. 305-324.

Chen, H.M. and Chung, H.M. (2017), “A scale for CEO personal brand measurement”, South African Journal of Business Management, Vol. 48 No. 2, pp. 23-32.

Close, A.G., Moulard, J.G. and Monroe, K.B. (2011), "Establishing human brands: determinants of placement success for first faculty positions in marketing", Journal of the Academy of Marketing Science, Vol. 39 No. 6, pp. 922-941.

Cross, J. (2015), “Arsene Wenger threatens to WALK OUT of Arsenal press conference over Mourinho comment and David Ospina questions", The Mirror, London, available at: https://www.mirror. co.uk/sport/football/news/arsene-wenger-threatens-walk-out-6558769 (accessed 20 November 2018).

Daily Mail (2018), “Arsene Wenger factfile”, Daily Mail, available at: https://www.dailymail.co.uk/ sport/football/article-323491/Arsene-Wenger-factfile.html (accessed 15 November 2018).

Dion, D. and Arnould, E. (2016), "Persona-fied brands: managing branded persons through persona", Journal of Marketing Management, Vol. 32 Nos 1-2, pp. 121-148.

English, N. (2018), "Arsene Wenger interview: the full transcript of his wide-ranging talk with RTL's Christine Kelly-football London", available at: https:/www.football.london/arsenal-fc/fullarsene-wenger-interview-rtl-14916477 (accessed 17 July 2018).

EPSN Staff (2017), “Arsenal boss Arsene Wenger accepts FA charge for Burnley incident”, available at: https://www.espn.com/soccer/arsenal/story/3046507/arsenal-boss-arsene-wenger-accepts-facharge-for-burnley-incident (accessed 5 February 2019).

Fetscherin, M. (2015), CEO Branding: Theory and Practice, Routledge, New York.

Flyvbjerg, B. (2011), "Case study”, in Denzin, N.K. and Lincoln, Y.S. (Eds), The Sage Handbook of Qualitative Research, Sage, Los Angeles, pp. 301-316.

Gad, T. and Rosencreutz, A. (2002), Managing Brand Me: How to Build Your Personal Brand, Momentum, London.

Godden, N. (2015), "Arsenal Boss Arsene Wenger admits he could manage another team if he is sacked. . .but insists it won't be in England", Daily Mail, London, available at: https://www. dailymail.co.uk/sport/football/article-3311695/Arsene-Wenger-admits-manage-team-Arsenalsack-insists-won-t-England.html (accessed 20 November 2018).

Gorbatov, S., Khapova, S.N. and Lysova, E.I. (2018), "Personal branding: interdisciplinary systematic review and research agenda", Frontiers in Psychology, Vol. 9, p. 2238.

Grohmann, K. (2015), “Arsenal out to tame 'angry' Bayern Munich again”, available at: https:/in. reuters.com/article/uk-soccer-champions-fcb-ars-preview/arsenal-out-to-tame-angry-bayernmunich-again-idUKKCNOSS04Q20151103 (accessed 20 November 2018).

Harris, F. and de Chernatony, L. (2001), "Corporate branding and corporate brand performance", European Journal of Marketing, Vol. 35 Nos 3/4, pp. 441-456.

Hasaan, A., Kerem, K., Biscaia, R. and Agyemang, K.J. (2016), "Understanding the implications of athlete brand among fans", Technics Technologies Education Management, Vol. 11 No. 1, pp. 68-81. 
Hasaan, A. (2016), "Cristiano Ronaldo as an athlete brand: a qualitative study", The 9th Conference of the Baltic Sport Science Society. Current Issues and New Ideas in Sport Science, Kaunas, Lithuania, p. 69.

Heere, B. and James, J.D. (2007), "Sports teams and their communities: examining the influence of external group identities on team identity", Journal of Sport Management, Vol. 21 No. 3, pp. 319-337.

Herskedal, K.M. (2017), Exploring the Managerial Cycle of Professional Football League Managers in England and Norway, Doctoral thesis, Liverpool John Moores University.

Hruschka, D.J., Schwartz, D., St John, D.C., Picone-Decaro, E., Jenkins, R.A. and Carey, J.W. (2004), "Reliability in coding open-ended data: lessons learned from HIV behavioral research", Field Methods, Vol. 16 No. 3, pp. 307-331.

Hughes, M., Hughes, P., Mellahi, K. and Guermat, C. (2010), "Short-term versus long-term impact of managers: evidence from the football industry”, British Journal of Management, Vol. 21 No. 2, pp. 571-589.

Hytner, D. (2018), "Arsène Wenger insists he will honour contract and stay at Arsenal", Online, The Guardian, London, available at: https:/www.theguardian.com/football/2018/feb/28/arsenewenger-arsenal-gary-neville-contract (accessed 22 November 2018).

Kapferer, J.-N. (2012), The New Strategic Brand Management Advanced Insights and Strategic Thinking, Kogan Page, London.

Keshtidar, M., Sahebkaran, M., Talebpour, M. and Kalashi, M. (2018), "Investigating the effect of brand identity and character on brand loyalty of football team fans", International Journal of Sport Management and Marketing, Vol. 18 Nos 1-2, pp. 105-115.

Koenigstorfer, J., Groeppel-Klein, A. and Kunkel, T. (2010), "The attractiveness of national and international football leagues: perspectives of fans of 'star clubs' and 'underdogs", European Sport Management Quarterly, Vol. 10 No. 2, pp. 127-163.

Koo, J.J. (2009), Brand Management Strategy for Korean Professional Football Teams: A Model for Understanding the Relationships between Team Brand Identity, Fans' Identification with Football Teams, and Team Brand Loyalty, Brunel University School of Engineering and Design, $\mathrm{PhD}$ Theses.

Kotler, P. and Kotler, M. (2012), Market Your Way to Growth: 8 Ways to Win, John Wiley \& Sons, Hoboken, New Jersey.

Kristiansen, E. and Williams, A.S. (2015), "Communicating the athlete as a brand: an examination of LPGA star Suzann Pettersen”, International Journal of Sport Communication, Vol. 8 No. 3, pp. 371-388.

Kunkel, T. and Biscaia, R. (2020), "Sport brands: brand relationships and consumer behavior", Sport Marketing Quarterly, Vol. 29, pp. 3-17.

Kunkel, T., Funk, D. and King, C. (2014), "Developing a conceptual understanding of consumer-based league brand associations", Journal of Sport Management, Vol. 28 No. 1, pp. $49-67$.

Lair, D.J., Sullivan, K. and Cheney, G. (2005), "Marketization and the recasting of the professional self: the rhetoric and ethics of personal branding", Management Communication Quarterly, Vol. 18 No. 3, pp. 307-343.

Langshaw, M. (2018), “Arsenal boss Arsene Wenger: 'Gunners fans don't hate me”, Sportsmole, London, available at: https:/ws.sportsmole.co.uk/football/arsenal/news/wenger-arsenal-fansdont-hate-me_320484.html (accessed 18 November 2018).

Lawrence, A. (2018), The Wenger Revolution: Twenty Years of Arsenal, Bloomsbury Sport, London.

Lingard, L. (2019), "Beyond the default colon: effective use of quotes in qualitative research", Perspectives on Medical Education, Vol. 8 No. 6, pp. 360-364. 
IJSMS

23,1

Lobpries, J., Bennett, G. and Brison, N. (2017), "Mary Ann to her Ginger: comparing the extended brand identity of two elite female athletes", International Journal of Sports Marketing and Sponsorship, Vol. 18 No. 4, pp. 347-362.

Lombard, M., Snyder-Duch, J. and Bracken, C.C. (2002), "Content analysis in mass communication: assessment and reporting of intercoder reliability", Human Communication Research, Vol. 28 No. 4 , pp. 587-604.

Lunardo, R., Gergaud, O. and Livat, F. (2015), "Celebrities as human brands: an investigation of the effects of personality and time on celebrities' appeal", Journal of Marketing Management, Vol. 31 Nos 5-6, pp. 685-712.

Mann-Bryans, M. (2018), "Arsene Wenger uneasy with long goodbye”, The Independent, London, available at: https://www.independent.ie/sport/soccer/arsene-wenger-uneasy-with-longgoodbye-36893907.html (accessed 20 November 2018).

Marquardt, K.L., Pemstein, D., Sanhueza Petrarca, C., Seim, B., Wilson, S.L., Bernhard, M., Coppedge, M. and Lindberg, S.I. (2017), Experts, Coders, and Crowds: An Analysis of Substitutability, V-Dem, Working Paper, Vol. 53.

McNally, D. and Speak, K.D. (2011), Be Your Own Brand, Berrett-Koehler Publishers, San Francisco.

Mokbel, S. (2017a), "Arsenal major owner Stan Kroenke says 'shares are not, and never have been, for sale' after £1bn Alisher Usmanov takeover is rejected”, Daily Mail, London, available at: https:// www.dailymail.co.uk/sport/football/article-4529818/Stan-Kroenke-underlines-commitmentArsenal.html (accessed 14 November 2018).

Mokbel, S. (2017b), "Arsene Wenger labelled Anthony Taylor 'dishonest to his federation' as Arsenal Boss earned four-match ban for pushing and swearing at official", Daily Mail, London, available at: https://www.dailymail.co.uk/sport/football/article-4246206/Arsenal-news-Arsene-Wengersaid-Anthony-Taylor.html (accessed 13 November 2018).

Mokbel, S. (2017c), "PSG interested in Arsenal Boss Arsene Wenger as French club's humiliation at hands of Barcelona threatens to impact Unai emery's future in Paris", Daily Mail, London, available at: https://www.dailymail.co.uk/sport/football/article-4298594/Arsenal-break-silenceArsene-Wenger-s-future.html (accessed 14 November 2018).

Mokbel, S. and Morshead, S. (2017), "Arsenal announce two-year deal for Arsene Wenger to stay as Frenchman commits to premier league title challenge: 'I love this club”, Daily Mail, London, available at: https://www.dailymail.co.uk/sport/football/article-4557926/Arsenal-announce-twoyear-deal-manager-Arsene-Wenger.html (accessed 2018).

Mokbel, S. and Williams, G. (2018), "Wenger hits back over questions about Arsenal future as Arsenal manager: 'I turned down the whole world to respect my contract", Daily Mail, 28 February, p. 20 November.

Montoya, P. and Vandehey, T. (2009), The Brand Called You, McGraw Hill, New York.

Moore, G. (2018), “Arsene Wenger: philosophy, politics and parents-*Le Professeur* opens up on life at Arsenal", The Independent, London, available at: https:/www.independent.co.uk/sport/ football/premier-league/arsene-wenger-resigns-quits-arsenal-interview-philosophy-politicsparents-a8314236.html (accessed 20 November 2018).

Morrow, S. and Howieson, B. (2014), "The new business of football: a study of current and aspirant football club managers", Journal of Sport Management, Vol. 28 No. 5, pp. 515-528.

Muñiz, A.M., Norris, T. and Fine, G.A. (2014), "Marketing artistic careers: Pablo Picasso as brand manager", European Journal of Marketing, Vol. 48 Nos 1/2, pp. 68-88.

Murray, R. (2017), "What is the difference between a personal brand and a corporate brand?", Online, available at http://robert-murray.com/personal-vs-corporate-brand/ (accessed 26 December 2018).

Osorio, M.L., Centeno, E. and Cambra-Fierro, J. (2020), "A thematic exploration of human brands: literature review and agenda for future research", Journal of Product and Brand Management, Vol. 29 No. 6, pp. 695-714. 
PA Sport (2016a), “Arsene Wenger asks for perspective from Arsenal fans”, Eurosport, London, available at: https://www.eurosport.com/football/arsene-wenger-asks-for-perspective-fromarsenal-fans_sto5545395/story.shtml (accessed 20 November 2018).

PA Sport (2016b), "Arsene Wenger responds to the latest round of criticism aimed at him and Arsenal", Eurosport, available at: https:/www.eurosport.com/football/premier-league/20152016/arsene-wenger-responds-to-the-latest-round-of-criticism-aimed-at-him-and-arsenal_ sto5283464/story.shtml (accessed 7 July 2020).

PA Sport (2016c), “Arsene Wenger won't let memory of stoke loss derail plan for success this season”, Eurosport, available at: https://www.eurosport.com/football/premier-league/2015-2016/arsenewenger-won-t-let-memory-of-stoke-loss-derail-plan-for-success-this-season_sto5059958/story. shtml (accessed 15 September 2020).

PA Sport (2017), "You have to control what you say about players, Warns Arsene Wenger", Belfast Telegraph, Belfast, available at: https:/www.belfasttelegraph.co.uk/sport/football/premierleague/you-have-to-control-what-you-say-about-players-warns-arsene-wenger-35687885.html (accessed 20 November 2018).

Pihl, C. (2013), "In the borderland between personal and corporate brands-the case of professional bloggers", Journal of Global Fashion Marketing, Vol. 4 No. 2, pp. 112-127.

Pitt-Brooke, J. (2018), "Brexit: premier league reject football association plans to limit number of foreign players", The Independent, London, available at: https:/www.independent.co.uk/sport/ football/premier-league/brexit-premier-league-foreign-players-quota-homegrown-epl-footballassociation-a8645571.html (accessed 21 November 2018).

Press Association (2016), "Arsene Wenger ignores 'boring' speculation on Arsenal future", Belfast Telegraph, London, available at: https:/www.belfasttelegraph.co.uk/sport/football/premierleague/arsene-wenger-ignores-boring-speculation-on-arsenal-future-34519639.html (accessed 20 November 2018).

Press Association (2018), "Arsene Wenger uneasy with long goodbye”, The Press, York, available at: https:/www.yorkpress.co.uk/sport/national/16217614.arsene-wenger-uneasy-long-goodbye/ (accessed 20 November 2018).

$\mathrm{Pu}, \mathrm{H}$. and James, J. (2017), "The distant fan segment: exploring motives and psychological connection of international national basketball association fans", International Journal of Sports Marketing and Sponsorship, Vol. 18 No. 1, pp. 418-438.

Qara (2019), "Sports industry insights", available at: https://medium.com/qara/sports-industry-report3244bd253b8 (accessed 5 March 2021).

Rein, I., Kotler, P., Hamlin, M. and Stoller, M. (2006), High Visibility Transforming Your Personal and Professional Brand, McGraw-Hill, New York.

Robinson, N. (2016), "Wenger Anger as city stun Arsenal on day of comebacks", Reuters, available at: https://www.reuters.com/article/uk-soccer-england/wenger-anger-as-city-stun-arsenal-on-day-ofcomebacks-idUKKBN1470V1 (accessed 21 November 2018).

Rohde, M. and Breuer, C. (2017), "The market for football club investors: a review of theory and empirical evidence from professional European football", European Sport Management Quarterly, Vol. 17 No. 3, pp. 265-289.

Schafraad, P., Wester, F. and Scheepers, P. (2006), 'Using 'new' data sources for 'old' newspaper research: developing guidelines for data collection”, Communications, Vol. 31 No. 4, pp. 455-467.

Scheidt, S., Gelhard, C., Strotzer, J. and Henseler, J. (2018), "In for a penny, in for a pound? Exploring mutual endorsement effects between celebrity CEOs and corporate brands", Journal of Product and Brand Management, Vol. 27 No. 2, pp. 203-220.

Schroeder, J.E. (2005), “The artist and the brand”, European Journal of Marketing, Vol. 39 Nos 11/12, pp. 1291-1305.

Schyns, B., Gilmore, S. and Dietz, G. (2016), "What lessons can we learn from football about leadership and management?”, in Peus, C., Braun, S. and Schyns, B. (Eds), Leadership Lessons from

Brand persona of a football manager 
IJSMS

23,1

Compelling Contexts Monographs in Leadership and Management, Emerald Group, Bingley, pp. 95-127.

Snowball, B. (2015), “Arsene Wenger: I may look constipated, but I do have a funny side. . .and I'm a big Bob Marley fan”, Eurosport, available at: https://www.eurosport.com/football/premierleague/2014-2015/bob-marley-fan-arsene-wenger-has-a-funny-side.-but-he-wont-share-it_ sto5015118/story.shtml (accessed 20 October 2020).

Speed, R., Butler, P. and Collins, N. (2015), "Human branding in political marketing: applying contemporary branding thought to political parties and their leaders", Journal of Political Marketing, Vol. 14 Nos 1-2, pp. 129-151.

Streb, C.K. (2010), "Exploratory case study", in Mills, A.J., Durepos, G. and Wiebe, E. (Eds), Encyclopedia of Case Study Research, Sage, Los Angeles, CA, pp. 372-373.

Summers, J. and Morgan, M.J. (2008), "More than just the media: considering the role of public relations in the creation of sporting celebrity and the management of fan expectations", Public Relations Review, Vol. 34 No. 2, pp. 176-182.

Taniyev, O. and Gordon, B.S. (2019), "Crafting a legacy: investigating the retired athlete brand image", International Journal of Sports Marketing and Sponsorship, Vol. 20 No. 3, pp. 390-406.

Tarnovskaya, V. and Bertilsson, J. (2017), Brand Theories: Perspectives on Brands and Branding, Studentlitteratur, Lund.

Tolson, A. (2001), "Being yourself': the pursuit of authentic celebrity", Discourse Studies, Vol. 3 No. 4, pp. 443-457.

Urde, M. (2013), “The corporate brand identity matrix”, Journal of Brand Management, Vol. 20 No. 9, pp. $742-761$.

Vallerand, R.J., Blanchard, C., Mageau, G.A., Koestner, R., Ratelle, C., Léonard, M., Gagné, M. and Marsolais, J. (2003), "Les passions de l'ame: on obsessive and harmonious passion", Journal of Personality and Social Psychology, Vol. 85 No. 4, pp. 756-767.

Van Riel, C.B.M. and Balmer, J.M.T. (1997), "Corporate identity: the concept, its measurement and management”, European Journal of Marketing, Vol. 31 Nos 5/6, pp. 340-355.

Wagg, S. (2007), "Angels of us all? Football management, globalization and the politics of celebrity", Soccer and Society, Vol. 8 No. 4, pp. 440-458.

Wilson, R., Plumley, D. and Flint, S.W. (2019), "Making sense of the sack race: the impact of managerial change in the English Football League", Sport, Business and Management: An International Journal, Vol. 10 No. 1, pp. 3-15.

\section{Corresponding author}

Adele Berndt can be contacted at: adele.berndt@ju.se

For instructions on how to order reprints of this article, please visit our website:

www.emeraldgrouppublishing.com/licensing/reprints.htm

Or contact us for further details: permissions@emeraldinsight.com 